\title{
Increased Competitive Advantage and Supply Chain Management Improve Company Performance (Case Study in Mild Steel Rollforming Companies in East Java)
}

\author{
Anisah $^{1}$ and Liliana Dewi ${ }^{2}$ \\ ${ }^{1}$ Universitas Ciputra, Surabaya, Indonesia \\ ${ }^{2}$ International Business Management, Universitas Ciputra, Surabaya, Indonesia
}

\begin{abstract}
This research aims to identify the impact of supply chain management to company performance and advantage of roll-forming light steel manufacture company in East Java. The data collection was done by submitting list of questions. The data was analyzed using path analysis. This research elaborates supply chain management variable (X1), company performance variable (Y1), and competitive advantage (Y2). Results of the path analysis show that there are 3 positive and significant hypotheses.

The first hypothesis is that supply chain management brings significant impact to company performance. The second hypothesis is that supply chain management brings significant impact to competitive advantage, and the third hypothesis is that competitive advantage brings significant impact company performance. VAF (Variance Accounted For) score for intermediary variable tends to be partial mediation.
\end{abstract}

Corresponding Author:

Liliana Dewi

Idewi@ciputra.ac.id

Received: 30 December 2019 Accepted: 29 January 2020 Published: 6 February 2020

Publishing services provided by Knowledge E

(c) Anisah and Liliana Dewi. This article is distributed under the terms of the Creative Commons Attribution License, which permits unrestricted use and redistribution provided that the original author and source are credited.

Selection and Peer-review unde the responsibility of the 6 th ICOEN 2019 Conference Committee.

\section{OPEN ACCESS}

Keywords: supply chain management, company performance, competitive advantage

\section{Introduction}

When global warming and go green socialization is trending, the country starts to ban the use of wood material without evident profit. Societies, who previously use wood material for roof truss, now start switching to steel material. The shift use of steel material has brought impact to the development of construction science and technology. The use of easel frame and roof, from wood to light steel, increases the number of steel industry significantly. The increasing steel consumption is seen as a big chance for steel industry person to develop their business, in line with the growth target of steel consumption in Indonesia. In order to make steel company work along with growth steel consumption in Indonesia, business doer must be able to pay attention to resource 
management strategies and to maintain the existence of strategy represented in supply chain management. Supply chain is an integrated process in which material and information flow is distributed within and between several entities including suppliers, manufacturers, distributors, retailers and customers. The main purpose of supply chain management is to meet customer requests more efficiently. Some light steel companies facing obstacles in their supply chain process, such as raw material scarcity, distribution delay, and price increase. These obstacles causing late production and distribution process, so a company needs choose right suppliers that provide good price and good quality with right delivery schedule. Choosing the right suppliers can keep company performance seen which can be seen from the sales, if there is any delay or out of stock, it can lose sales or lose the opportunity to get customers. This will worsen the company performance. Performance is a benchmark of company or individual work. (9, Hasibuan (2001: 34) Performance (work performance) is a result of work achieved by someone in carrying out his tasks based on his skills, experience, seriousness, and working time. Company performance can be seen from the profits earned, targets achievement, growth, innovation, and asset returns. In managing company performance both financially or operational, companies must also be able to maintain good relationship with suppliers and customers to be able to exchange information between customer needs and availability of goods to suppliers.

Companies must maintain intensive communication with suppliers and customers, approach both suppliers and customers personally. This is done to gain trust from suppliers and customers in order to establish good relationship so that supply chain management not only can improve company performance but also improve company's competitive advantage. Competitive advantage in light steel industry can be achieved if the chain from raw materials to consumers is well-managed in value and cost. To achieve competitive advantage, information strategies are needed. According to 19 , Yaqoub (2012) Information sharing is the intensity and capacity of companies in their interactions to share information with partners in relation to joint business strategies.

(14, Prabusankar (2017) wrote a paper entitled Impact of Supply Chain Management Practices on Competitive Advantage of Small Manufacturing Firms in Coimbatore District. He did a quantitative research which resulted supply chain management using strategic supplier partnership, information quality, internal lean practice, information sharing, and customer relationship has positive and significant influence to competitive advantage of small manufacturing companies.

(5, Dwiyanto (2013) An Analysis of Supply Chain Management Impact to Company Performance, a study of small and medium industries of Padang, West Sumatra typical 
processed-food. Based on the research results, variables in this research, which include information sharing, long term relationship, cooperation, and process integration give positive and significant impact to supply chain management practice of company performance.

(4, Doung and Nguyen (2018) wrote a paper entitled The Impact of Supply Chain Management, Competitive Advantage to Company Performance. Results of the study show that supply chain management and competitive advantage give positive and significant impact to company performance.

Supply chain management is a whole integrated task of coordination flow to comply customer needs by improving advantage of the whole supply chain system (1, Adebayo, 2012). According to (16, Russell and Bernard (2006:12), supply chain management focuses on integrating and managing the flow of goods and service through supply chain in order to be responsive to customer needs and to press total cost. Right supplier is not only that can provide good material with good price in the nick of time, but also give optimal service for being responsive and delivering good communication and information (18, Yoserizal and Singgih, 2012: 75).

According to Li et al. (2006), in integrated supply chain, there are indicators which include strategic supplier partnership, customer relationship, and information sharing.

(3, David and Simon (2011) stated that competitive advantage is a capacity of an organization to create and keep the competition over their competitors. (2, Attiany (2014) stated that to establish sustainable competitive advantage, a company must have differentiated product from their competitors, without putting aside product use and suitability to the customers.

Some indicators to score a company's competitive advantage, according to 12 , Li et al. (2006), scoring company competitive advantage can be done using indicators; price, quality, delivery dependability, product innovation, and time to market.

(13, Mutia (2009) defined performance as the work result which can be achieved by someone or by a group of people in a company based on their authorities and responsibilities in order to achieve the company goals.

Some indicators to score company performance which commonly used in empirical research are financial performance, operational performance, and market-based performance (11, Jahanshahi, 2012). 


\section{Methods}

Data in this study was collected using questionnaires. Variables were measured using Likert scale with range 1-5 from very strongly disagree to strongly agree. The population of this research is 41 light steel roll-forming companies, each of which has suppliers, light steel production, customers, and distribution channel. The research took place at light steel roll- forming manufacturing companies in several cities of East Java including Surabaya, Gresik, Malang, Lamongan, Mojokerto, Magetan, Banyuwangi, Madiun, Sidoarjo, and Bojonegoro.

In this study, there are 3variables; supply chain management (X1), company performance (Y1), and competitive advantage (Y2) as mediator. Some hypotheses will be further tested. The analysis model can be seen as follows:

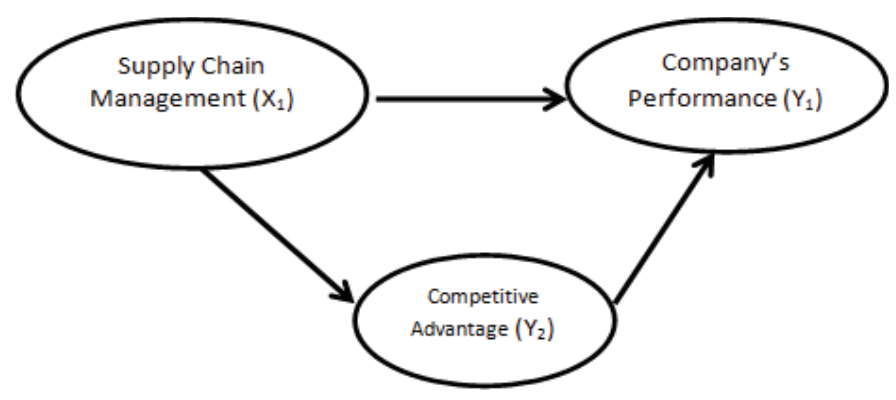

Figure 1: Hypothesis Framework (Source: edited author 2019).

Based on the background, research questions, and the previous research that has been mentioned above, the hypothesis proposed in this study are as follows:

H1: Supply chain management is significant to company performance of Light Steel Roll-forming Manufacture Company in East Java

$\mathrm{H} 2$ : Supply chain management is significant to competitive advantage of Light Steel Roll-forming Manufacture Company in East Java

H3: Competitive advantage is significant to company performance of Light Steel Rollforming Manufacture Company in East Java

The research was carried out from June 2018 to January 2019. The analytical method used in this research is path analysis method, to analyze correlation pattern between variables. The model is implemented to find out the direct or indirect impact of a set of independent variables to dependent variables (17, Sani and Maharani 2013: 74). Validity test is an index that shows the measuring instrument really measures what needs to be measured. The instrument used to assess the validity test is the Pearson correlation test instrument. Reliability is tested using Cronbach Alpha, if the score of Cronbach Alpha is $>0.60$, then the question is reliable. Hypotheses are tested using $F$ test and 
$\mathrm{t}$ test. Test F, according to (8, Gujarati (2003: 257), is used to measure the goodness of fit of regression equality or to find out if all independent variables in the equation affect the dependent variable. If the significance score in $F$ test is $<0.05$, it can be concluded that the independent variables simultaneously give significant impact to the dependent variable. $T$ test hypothesis testing is a significance test to find out if there is any correlation between these variables (15, Priyatno, 2012: 109). The significance score in the $t$ test is $<0.05$.

\section{Results}

\subsection{Validity and Reliability Test}

Based on the item analysis test of supply chain management variable (X1), Company Performance (Y1), and Competitive Advantage (Y2), it can be seen that the significant score of Pearson Correlation per indicator is $<0.05$. Thus, the validity test on this indicator is valid. The reliability test of Cronbach alpha score to all variables in this study is $>0.60$, in which the alpha score between Supply Chain Management variable is 0.895 , greater than that between competitive advantage variable which only reaches 0.858. The Cronbach alpha score for Company performance is 0.879 . From the results of reliability test, it can be inferred that the measurement instrument used in this study is reliable.

\subsection{Regression Analysis}

$$
Y 2=\rho 2 X 1
$$

Model
(Constant)
Supply Chain
Management

\begin{tabular}{|c|c|}
\hline Unstandardized Coefficients \\
\hline B & Std. Error \\
\hline 1.423 & .479 \\
\hline .679 & .123 \\
\hline
\end{tabular}
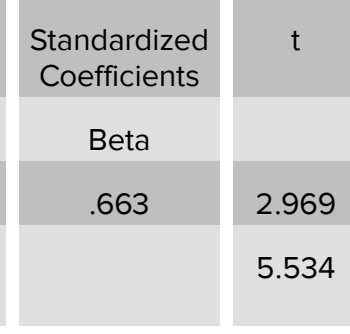

Sig.

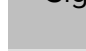

.005

5.534

.000

$Y 2=0.663 X 1$ 
The standardized supply chain management beta score of 0.663 is the path score or ( $p 2)$ and is significant at 0,000 which means that supply chain management is significantly affect positively competitive advantage. The higher supply chain management score is, the higher the competitive advantage score be.

$$
Y 1=\rho 1 X 1+\rho 3 Y 2
$$

\begin{tabular}{|l|l|}
\hline Model \\
\hline $1 \quad$ & (Constant) \\
& $\begin{array}{l}\text { Supply Chain } \\
\text { Management } \\
\text { Competitive } \\
\text { Advantage }\end{array}$ \\
\hline
\end{tabular}

\begin{tabular}{|c|c|}
\hline Unstandardized Coefficients \\
\hline B & Std. Error \\
\hline .472 & .473 \\
\hline .497 & .146 \\
\hline .434 & .143 \\
\hline
\end{tabular}
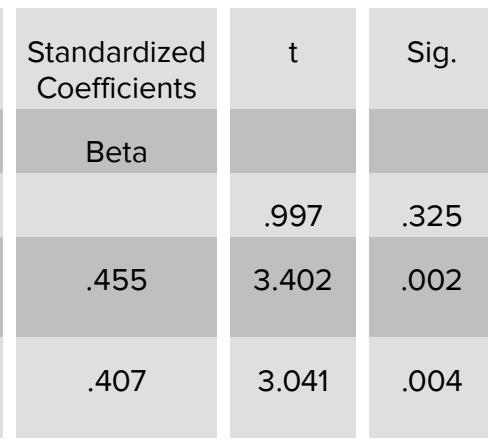

$$
Y 1=0.455 X 1+0.407 Y 2
$$

The standardized competitive advantage beta score of 0,455 is the path score or (p1) and is significant at $0,002<$ sig. 0.05 which means that supply chain management is significantly affect positively competitive advantage. The higher supply chain management score is, the higher company performance score be.

While the standardized competitive advantage beta score of 0,455 is the path score or ( $\rho 3$ ) and is significant at 0,004 < sig. 0.05 which means that competitive advantage is significantly affect positively company performance. The higher competitive advantage score is, the higher company performance score be.

\subsection{Hypothesis Test}

\subsection{1. $t$ Test}

At the first equation of sig score, the t-statistics variable is $<0.05$ so the null hypothesis of the study is declined. In other words, the independent variable of supply chain management is partially affect competitive advantage significantly. At the second equation of sig score. T- statistics of the two variables are 0.002 and 0.004 ; each is $<0.05$ so the null hypothesis of the study is declined. Thus, it can be concluded that independent 
variables of supply chain management and competitive advantage are partially affect company performance significantly.

\subsubsection{F test}

At the first equation of sig score, $\mathrm{F}$ statistic on supply chain management regression to competitive advantage is 0,000 . With $95 \%$ level of assurance $(\alpha=0.05)$, hypothesis is declined because of the sig score of F-statistic $<\alpha$. Therefore, supply chain management variable affect competitive advantage positively and significantly. At the second equation, $\mathrm{F}$ statistics on supply chain management regression and competitive advantage to company performance is 0,000 . With $95 \%$ level of assurance $(\alpha=0.05$ ), research hypothesis is declined because of the sig score F-statistic $<\alpha$. Thus, it can be concluded that the supply chain management variable and advantage affect company performance positively and significantly.

\subsubsection{Coefficient of Determination (R2)}

The first equation of analysis results shows that $\mathrm{R} 2$ coefficient score is 0.440 , which means that supply chain management variable explains $44 \%$ variability of competitive advantage variable. The remaining $56 \%$ is explained by other variables which are not tested by this research. Second equation of analysis results shows that R2 coefficient price is 0.619. It can be concluded that Supply Chain Management and competitive advantage variables can explain variability of $61.9 \%$ company performance variable, while the remaining $38.1 \%$ is explained by other variables which are not tested by this research.

\subsection{Direct-Indirect Effect}

1. Direct Effect of supply chain management to company performance

$$
X 1 \rightarrow Y 1=p 1=0,455
$$

(2) Indirect effect of supply chain management to company performance through competitive advantage

$$
X 1 \leftarrow Y 2 \rightarrow Y 1=p 2 \times p 3=0,663 \times 0,407=0,269
$$


(3) Total effect of supply chain management to copany performance and competitive advantage

Total X1Y2Y1 $=p 1+(p 2 \times p 3)=0.455+(0,663 \times 0,407)=0.725$

(4) VAF score $=$ indirect effect / total effect. (Joseph et al., 2016)

$=(p 2 \times p 3) /(p 1+(p 2 \times p 3))$

$=0,269 / 0.725$

$=0.371$

\section{Discussion}

From the calculation of the effect between paths, it can be seen that the direct effect of supply chain management to company performance is 0.455 . The indirect effect of supply chain management to company performance through competitive advantage is 0.269. In path analysis model, the significance intervening variable score can be measured using VAF calculation method. Based on VAF calculation result of 0.371 or $37.1 \%$, it can be concluded that competitive advantage as an intermediary variable is partial mediation.

\subsection{The Impact of Supply Chain Management to Company Perfor- mance}

Results of data analysis show that supply chain management affect company performance positively and significantly with $t$ sig. score $0.002(<0.05)$. It means that the better the supply chain management is, the better company performance is. Supply chain management which scored using three indicators; strategic supplier partnerships, customer relationship, and information sharing has significant role on company performance of light steel roll-forming manufacture company in East Java. According to (10, Heizer and Barry (2005), companies need to consider supply chain issues to ensure that the supply chain can support company's strategy. If the management operation function supports company's strategy, then the supply chain can be designed to support management operation strategies. This result is in line with the research done by (4, Doung and Nguyen, (2018) which stated that supply chain management affect company performance positively. 


\subsection{The Impact of of Supply Chain Management to Competitive Advantage}

Results of data analysis show that supply chain management affect competitive advantage positively and significantly with $\mathrm{t}$ sig. score $0,000(<0.05)$. It means that the better supply chain management performance is, the better competitive advantage of East Java, Indonesia light steel roll-forming manufacturing company is. Supply chain management is measured using three indicators: strategic supplier partnership, customer relationship, and information sharing. This result is in line with the research conducted by (14, Prabusankar (2017) which stated that supply chain management affect company's competitive advantage significantly. Competitive advantage can be seen from the cheaper price, better quality, and faster delivery time. Companies that have competitive advantage can bring company performance to a higher level and create customer satisfaction and loyalty. Competitive advantage according to (7, Goyal and Cardenas-Barron, 2001) is the ability of one company to earn economic profits above their competitors' profit of market in the same industry.

\subsection{The Impact of Competitive Advantages to Company Perfor- mance}

Results of data analysis shows that competitive advantage affect company performance positively and significantly with $\mathrm{t}$ sig. score $0.004(<0.05)$. It means that the better company competitive advantage is, the better company performance is. Competitive advantage is measured using five indicators including: price, quality, delivery dependability, product innovation and time to market, each of which has important role for East Java light steel roll- forming manufacture companies. This result is in line with the research done by (4, Doung and Nguyen (2018) which said that competitive advantage has a positive impact on organizational performance. Organizational performance is the real result or output produced by an organization which then measured and compared with the output or expected output (11, Jahanshahi, et al., 2012). Sustainable competitive advantage is where the organization heading, not as the final goal, as a tool to achieve organizational performance which resulted to relatively high profits (6, Ferdinand, 2003). 


\section{Conclusion}

Based on the elaborated research above, it can be inferred that: 1) Supply chain management is significantly affected company performance of light steel roll-forming manufacture companies in East Java. 2) Supply chain management is significantly affected competitive advantage of light steel roll-forming manufacture companies in East Java. 3) Competitive advantage is significantly affected company performance of light steel roll-forming manufacture companies in East Java.

\section{Research Limitation}

There are limit in this research which including the objection of some companies to provide their company performance record for initial survey purpose. The researcher also have limitation to adjust the schedule of company visit in different cities.

\section{Recommendations}

For Further Research: 1) The upcoming research is expected to expand the research by observing manufacture, service, and retail industries which have applied supply chain management practice formally. 2) The upcoming research is expected to observe respondents from East Java outside so they can do benchmarking and the research result will be more exact. 3) On the upcoming research, the researcher can use other instrument such as using SEM (Structural Equation Modeling) method to calculate the data.

For Companies: The companies are suggested to improve their supply chain performance in order to make their company performance and competitive advantage better. Companies can use indicators from this research variables, for example indicators of supply chain management variable are strategic supplier partnership, customer relationship, and information sharing. One thing that the companies can do is by applying information sharing management to coordinate supply chain members. By using information technology, they can manage fast-moving information to provide customers the best service. 


\section{Acknowledgement}

The authors would like to thank their colleague for their contribution and support to the research. They are also thankful to all the reviewers who gave their valuable inputs to the manuscript and helped in completing the paper.

\section{Conflict of Interest}

The authors have no conflict of interest to declare.

\section{References}

[1] Adebayo, I. T. (2012), 'Supply chain management (SCM) practices in Nigeria today: impact on SCM Performance'. European Journal of Business and Social Sciences, vol 1(6), 107- 115.

[2] Attiany, M. (2014). Competitive Advantage Through Benchmarking: Field Study of Industrial Companies Listed in Amman Stock Exchange. Journal of Business Studies, vol 5, pp. 41-45.

[3] David and Simon (2011). Resource Orchestration to Create Competitive Advantage: Breath Depth, and Like cycle Effects. Journal of Management, vol 37 (5), pp. 13901412.

[4] Doung V.X and H.H. Nguyen. (2018), 'Supply Chain Management Practices, Competitive Advantages and Firm Performance: A Case of Small and Medium Enterprises (SMEs) in Vietnam', Journal of Moderm Accounting and Auditing, vol 14, (3), pp. 136-146.

[5] Dwiyanto, (2013). Analisis Pengaruh Supply Chain Management Terhadap Kinerja Perusahaan. Jurnal Studi Manajemen \& Organisasi, Vol.10 (2).

[6] Ferdinand, A.T. (2003). Sustainable Competitive Advantage: Sebuah Explorasi Model Konseptual. Badan Penerbit Universitas Diponegoro,Semarang.

[7] Goyal, S.K and L.E. Cardenas-Barron. (2001), Note on:An Optimal Batch Size for a Production System Operating Under a Just In Time Delivery System', International Journal of Production Economics.

[8] Gujarati, D. (2003). Ekonomimetrika Dasar. Jakarta: Erlangga.

[9] Hasibuan, M. (2001). Manajemen Sumber Daya Manusia. Jakarta: PT Bumi Aksara.

[10] Heizer, J. and R. Barry. (2005) Operations Management. Jakarta: Salemba Empat. 
[11] Jahanshahi, A.A., (2012), 'Electronic Commerce Applications among Indian Small and Medium Enterprises', Information Management and Business Review, Vol 2(6), pp. 276-286.

[12] Li, S., Ragu-Nathan,B., Ragu-Nathan, T.S. and Subba Rao, S. (2006) 'The Impact of Supply Chain Management Practise on Competitive Advantage and Organizational Performance', Omega, Vol 34(1), pp. 107--124.

[13] Mutia, N. (2009) Usulan Rancangan Kinerja Perusahaan. Jakarta: Universitas Indonesia.

[14] Prabusankar, R. (2017), 'Impact Of Supply Chain Management Practices On Competitive Advantage Of Small Manufacturing Firms In Coimbatore District'. International Journal of Mechanical Engineering and Technology, Vol 8(10), pp. 836$-843$.

[15] Priyatno, D. (2012). Cara Kilat Belajar Analisis Data dengan SPSS 20. Yogyakarta: Andi.

[16] Russell, R.S. and W.T. Bernard. (2006) Operations Management-Quality and Competitiveness in a Global Environment, fifth ed., America: John Wiley \& Sons, Inc.

[17] Sani A.S. and V. Maharani. (2013) Metodologi Penelitian Manajemen Sumber Daya Manusia. Malang: UIN-Maliki Press.

[18] Yoserizal, Y and Singgih, M. L. (2012). Integrasi Metode Dematel (Decision Making Trial and Evaluation Laboratory) dan ANP (Analytical Network Process) dalam Evaluasi Kinerja Supplierdi PT. XYZ. Prosiding Seminar Nasional Manajemen Teknologi ITS, (15), pp. 71- 78.

[19] Yaqoub, M.A. (2012), 'Pengaruh Mediasi kepercayaan Pada Hubungan Antara Kolaborasi Supply Chain Dan Kinerja Operasi'. Jurnal Manajemen \& Kewirausahaan,Vol. 14(2). 